\title{
Effects of flow-controlled vacuum on milking performance and teat condition in a rotary milking parlor
}

\author{
D. J. Reinemann, ${ }^{1 *} \odot$ B. H. P. van den Borne, ${ }^{2} \odot$ H. Hogeveen, ${ }^{2} \odot$ M. Wiedemann, ${ }^{3} \odot$ and C. O. Paulrud ${ }^{4} \odot$ \\ ${ }^{1}$ Department of Biological Systems Engineering, University of Wisconsin-Madison, Madison 53706 \\ ${ }^{2}$ Business Economics Group, Wageningen University, $6706 \mathrm{KN}$, the Netherlands \\ ${ }^{3}$ DeLaval GmbH, 21509 Glinde, Germany \\ ${ }^{4}$ DeLaval International, Tumba 14741 , Sweden
}

\section{ABSTRACT}

The objective of this study was to compare a vacuum control system that increases milking system vacuum during the peak flow period of milking to conventional constant vacuum control technology regarding its effect on milk flowrate and milking duration. Further objectives were to study the effects of flow-controlled vacuum on milking parlor performance. An observational study was conducted on a commercial dairy farm milking from 848 to 896 cows per day over the study period using a 60-stall rotary milking parlor. The flow-controlled vacuum control system was applied for 3 wk. Milking performance and teat condition were compared with 3 -wk periods prior and subsequent to the test period using conventional vacuum control. Statistical analysis was performed assuming a cross-sectional study design during each period. Flow-controlled vacuum increased peak milk flowrate by $12 \%$ and increased average milk flowrate by $4 \%$. The decrease in individual cow milking duration was proportional to milk yield per milking. Postmilking teat condition was good during the entire study period. The occurrence of rough teat ends was slightly reduced during the flow-controlled vacuum period with no meaningful difference in the occurrence of teats with blue color, palpable rings, or petechia. The combination of reduced vacuum during the low flow period of milking and the decrease in milking duration are likely factors that are protective of teat tissues. Bioeconomic modeling of the use of flow-controlled vacuum on the performance of rotary milking parlors, using the data that were collected during the study, showed that the reduction in milking duration of individual cows allows a higher rotary parlor speed. Modeled parlor throughput increased by $5.0 \%$ to 419 cows/h, $6.8 \%$ to $407 \mathrm{cows} / \mathrm{h}$, and $4.2 \%$ to 326 cows/h when $80 \%, 95 \%$, and $99 \%$ of the cows were finished milking at the end of

Received August 5, 2020.

Accepted February 6, 2021.

*Corresponding author: Doug.Reinemann@wisc.edu the rotation for a 60 -stall parlor. Model results showed that increased parlor throughput resulted in increased labor efficiency, reduced labor costs for milking, and a positive benefit-cost ratio on the investment for all but the smallest herd and parlor sizes considered.

Key words: milking machine performance, vacuum control, labor efficiency, milking speed

\section{INTRODUCTION}

One of the primary motivations to develop machine milking was to reduce the amount of time needed to harvest milk and thereby reduce labor requirements on dairy farms. Methods to increase milking speed have therefore been a source of inquiry since the very beginning of machine milking. Pulsation and vacuum settings in a conventional milking parlor offer a tradeoff between milking speed and teat tissue stress. Since the early days of milking machine research and until the present time, vacuum and pulsation settings have been widely studied (Smith and Petersen, 1946; Thomas et al., 1993; Gleeson et al., 2003) and in combination with other ways to increase milking speed such as liner design (Spencer et al., 2007; Bade et al., 2009), and optimal pre-milking stimulation (Odorčić et al., 2019). None of the studies cited above have used a dynamic control strategy to adjust machine settings during milking of an individual animal.

For a milking machine using conventional vacuum regulation, milkline vacuum is held at some steady level with an allowance for deviations of up to $2 \mathrm{kPa}$ during brief periods of unintended air admission, such as might occur when attaching milking units or when a milking unit falls off a cow. There is an inverse relationship between milk flowrate and claw vacuum with the highest claw vacuum occurring at the lowest milk flowrate. This "vacuum drop" is produced by frictional effects of moving the milk and air mixture through the long milk tube and by lifting milk, in the case of a mid- or high-level milkline. Teat tissue stress is therefore most severe during the low flow period of milking when the 
teat-end vacuum level is the highest, approaching the system vacuum (Besier et al., 2016). There are multiple causes of increased teat tissue stress during the low flow period of milking and the duration of the low flow period, during which teat-end vacuum is at its highest level, has been shown to have a substantial influence on adverse teat conditions observed after milking (Rasmussen, 2000; Hillerton et al., 2002; Reinemann et al. 2013).

Milking system vacuum levels are normally constant and range from $40 \mathrm{kPa}$ in low-level milklines up to 48 $\mathrm{kPa}$ for high-level milklines; the goal being to account for vacuum drop and achieve teat-end vacuum between 32 and $42 \mathrm{kPa}$ during the peak flow period of milking as specified in the ISO standard for milking machine construction and performance (ISO, 2007). A previous study compared 2 control strategies that adjust vacuum level according to milk flowrate (flow-controlled vacuum, or FCV). In a study with a sample of 10 cows, a milking system vacuum of 56 or $49 \mathrm{kPa}$ was applied during the peak flow period of milking, and a reduced milking system vacuum of $33 \mathrm{kPa}$ was applied during the low flow period in a high-level milkline system (Ambord and Bruckmaier, 2010), resulting in short milk tube vacuum levels during the peak flow period of from 41 to $51 \mathrm{kPa}$ or from 31 to $37 \mathrm{kPa}$ for high and low vacuum treatments, respectively. Clusters were removed $20 \mathrm{~s}$ after milk flowrate decreased to $<0.2$ $\mathrm{kg} / \mathrm{min}$. The authors reported that peak milk flowrate was higher for the system with higher vacuum during the peak flow period, but the overall speed of milking was the same for the 2 systems. They also reported that there was no increase in postmilking teat wall thickness for either system.

The study cited above, using a high-level milkline, indicated the potential for increasing peak milk flowrates by increasing milking vacuum during the peak flow period while avoiding teat tissue stress and congestion by reducing vacuum during the low flow period. Our goal was to investigate if the application of an FCV on a low-level milkline system could reduce milking duration while maintaining good postmilking teat tissue conditions. The vacuum dynamics are different for high-level compared with low-level milkline systems, and no comparable studies have been performed for the more common low-level milkline systems. The flow threshold in these previous studies is lower than what has become common practice. We were therefore also interested in investigating whether FCV combined with a higher cluster removal flow threshold, more typical for large commercial dairies, might result in reduced milking duration. We were further interested in expanding the sample size from the 10 cows used in previous studies to a large herd of cows representing a typical range of lactation number, stage of lactation, and milk production levels.

We hypothesized that an FCV applied to a lowlevel milkline system in combination with a higher milk flowrate threshold for teatcup removal strategy could reduce milking duration while avoiding negative effects on teat condition. It was further hypothesized that with shorter milking duration, one practical implication is that the speed of a rotary milking parlor could be increased, resulting in improved capital and labor efficiency.

The specific objectives of this study were to (1) measure the effects of an FCV regulation strategy on peak milk flowrate (PMF), average milk flowrate (AMF), milking duration (MD), and teat tissue condition on a large commercial dairy herd; and (2) estimate the annual labor costs savings of implementing this vacuum control strategy on large dairy herds using rotary milking parlors.

\section{MATERIALS AND METHODS}

The study farm was located in northern Germany. The farm milked 848 to 896 Holstein-Friesian cows per day with a 60-stall DeLaval PR3100HD rotary milking parlor with rotational speed of 11 to $12 \mathrm{~s}$ per stall (11 to 12 min per turn). The farm used DeLaval Clover liners. The average production level of the herd was $33.4 \mathrm{~kg} /$ cow per day during the study period. The herd used a variable milking frequency with individual pens of cows milked from 2 to 4 times per day, resulting in an average milking frequency for the herd of 2.7 times per day and average milk yield per milking of $12.2 \mathrm{~kg}$. Primiparous cows made up $30 \pm 2 \%$ of the herd over the course of the study. The milking procedures consisted of one worker positioned at the second stall past the entry point to perform premilking sanitation and one worker positioned at the seventh stall past the entry point to attach clusters. Postmilking teat disinfection was performed by a robotic arm positioned at the 55 th stall past the entry point. After cluster removal, clusters were treated with a system to allow air admission through teatcups and move milk remaining in the cluster into the milkline.

\section{Treatments}

All cows in the milking herd were enrolled in the study. Two vacuum control strategies were applied. The conventional vacuum control treatment $(\mathbf{C O N})$ operated by maintaining a constant $45 \mathrm{kPa}$ milkline vacuum during the entire milking process, resulting in average 
claw vacuum of 38 to $40 \mathrm{kPa}$ during the low flow period of milking and 36 to $38 \mathrm{kPa}$ during the peak flow period of milking. The alternate FCV strategy operated with $45 \mathrm{kPa}$ milkline vacuum when cluster milk flowrate was $<2 \mathrm{~kg} / \mathrm{min}$ and $49 \mathrm{kPa}$ milkline vacuum when cluster milk flowrate exceeded $2 \mathrm{~kg} / \mathrm{min}$, resulting in average claw vacuum of 38 to $40 \mathrm{kPa}$ during low flow period and 40 to $42 \mathrm{kPa}$ during the peak flow period of milking. The change of milkline vacuum was implemented at the cow/cluster level for the FCV treatment. For the purposes of this study the low flow period was defined as udder total milk flowrate $<2 \mathrm{~kg} / \mathrm{min}$ and the peak flow period as udder milk flowrate $>2 \mathrm{~kg} / \mathrm{min}$, because this was the milk flowrate threshold at which the increased vacuum level was applied. The farm had been using the CON settings for about $8 \mathrm{yr}$ since the installation of the parlor. During the first 3 wk of the study, milking performance data from the CON treatment was used $(\mathbf{C O N}-\mathbf{1})$. The FCV treatment was applied during the middle 3 wk of the study, and the CON treatment was again applied during the final 3 wk of the study $(\mathbf{C O N}-2)$. The pulsator ratio $(65: 35)$ and the switch-point for cluster removal $(0.4 \mathrm{~kg} / \mathrm{min})$ were constant across the study period and were the same as the farm had been using before the experiment. While a full crossover experimental design would have been ideal, it was not practical on the large commercial dairy farm to split the herd into 2 milking groups with 2 treatments applied simultaneously. For analysis of milking performance, we removed data from the day on which the treatments were changed, eliminating the last milking session of the prior treatment and the first 2 milking sessions of the new treatment. This was done to avoid any ambiguity on which treatment was applied and to reduce potential carryover effects in the analysis. Outliers or probable data errors were removed by filtering on extreme values for AMF $(<0.1 \mathrm{~kg} / \mathrm{min}$, $>6 \mathrm{~kg} / \mathrm{min})$, PMF $(<0.2 \mathrm{~kg} / \mathrm{min},>10 \mathrm{~kg} / \mathrm{min})$, and MD $(<100 \mathrm{~s},>800 \mathrm{~s})$ resulting in removal of less than $0.1 \%$ of the data.

\section{Milking Speed}

Data for MD, AMF (calculated as total yield/ $\mathrm{MD}$ ), and PMF (calculated as the maximum 60-s average milk flowrate) were obtained from the DelPro FarmManager software version 5.5 (http://www .delavalcorporate.com/our-products-and-services/farm -support/DelPro/) as recorded with MM27 milk meters (DeLaval). The effect of milking treatment on AMF, PMF, and MD was assessed using a PROC MIXED model (SAS Institute Inc.). Model terms included class variables treatment (CON or FCV) and lactation class
$(\mathbf{L} \mathbf{1}=$ primiparous, or $\mathbf{L} \mathbf{2}+=$ multiparous $)$, and continuous variables milk yield per milking (Yield) and DIM. Cow was declared as a repeated measure with first order autoregressive correlation structure.

\section{Teat Dimensions and Teat Condition}

Premilking teat dimensions and shape were recorded at the end of each period by one observer on as many cows as could be accomplished during the course of a normal milking ( $68 \%$ of quarters for CON-1, $69 \%$ of quarters for FCV, and $86 \%$ of quarters for CON-2). Cows were chosen so that all of the teat conditions could be scored (e.g., omitting cows with black teat skin), and all 4 quarters of each selected cow were scored for each condition. Teat shape (TS) was classified as either cylindrical or conical, and premilking teat length (TL) and mid-barrel teat diameter (TD) were measured.

A second observer recorded postmilking teat condition scores at the end of each treatment period for as many cows as possible (89\% of quarters for $\mathrm{CON}-1,87 \%$ of quarters for FCV, and $90 \%$ of quarters for CON-2). Postmilking teat tissue conditions assessed included the long-term response of teat-end hyperkeratosis (TEHK) scored as normal (no ring or smooth ring) or rough (rough or very rough ring), the medium-term response of Teat skin petechiation (TP) scored as normal or petechiae, and the short-term responses, teat color (TC) scored as normal or blue, and teat ringing (TR) scored as normal or palpable ring at the base of the teat. Teat condition data were treated as categorical outcomes as recommended by Reinemann et al. (2001).

Teat condition indicators were treated as observational/cross-sectional data collected at 3 points in time. McNemar's test for binary responses and paired subject data were used to assess differences in teat condition observations made at the end of the FCV period compared with the prior CON-1 period, and again to compare the observations at the end of the CON-2 period to the prior FCV period. It evaluated whether teats (1) tested normal in both periods, (2) tested problematic in both periods, (3) moved from normal to problematic, and (4) moved from problematic to normal. The null hypothesis was that the probabilities for each outcome (normal/problematic) are the same for each observation period.

An additional analysis was performed to examine the associations of several covariates on teat conditions during the FCV period using the following SAS PROC GLIMMIX model (SAS Institute Inc.):

$$
\mathrm{TTC}=\text { Lactation }+\mathrm{DIM}+\mathrm{MD}+\mathrm{TL}+\mathrm{TD}+\mathrm{TS},
$$


Table 1. Input parameter settings for simulating a rotary milking parlor in large dairy herds

\begin{tabular}{|c|c|c|c|c|c|c|c|c|}
\hline Herd size & Rotary size & \multicolumn{3}{|c|}{ Labor (number of employees) } & \multicolumn{4}{|c|}{ Nonutilized milking unit } \\
\hline 2,000 & 60 & 2 & 1 & 1 & 1 & 6 & 1 & 3.5 \\
\hline 3,000 & 60 & 2 & 1 & 1 & 1 & 6 & 1 & 3.5 \\
\hline 4,000 & 80 & 3.5 & 1 & 1.5 & 1 & 7 & 1 & 4.5 \\
\hline 7,000 & 100 & 4.5 & 1 & 1.5 & 1 & 8 & 1 & 5.5 \\
\hline
\end{tabular}

${ }^{1} \mathrm{PMTD}=$ postmilking teat disinfection .

where $\mathrm{TCC}=$ teat tissue condition $[\mathrm{TEHC}, \mathrm{TC}, \mathrm{TR}$, and TP, all binary variables (normal/problematic)]; Lactation $=\mathrm{L} 1$ or $\mathrm{L} 2+$, class variable; DIM = days in milk, continuous variable; $\mathrm{MD}=$ milking duration, continuous variable; $\mathrm{TL}=$ premilking teat length, continuous variable; $\mathrm{TD}=$ premilking, mid-barrel teat diameter, continuous variable; and TS = teat shape, cylindrical or conical, class variable.

We used the DIST $=$ BINOMIAL and LINK = LOGIT options to estimate the odds ratios, which is a good estimate of the relative risk when the event probability is low as indicated by Kiernan (2018). We also used the DDFM = satterth option to specify the Satterthwaite denominator degrees of freedom approximation. A "random_residual_" statement was used with cow declared as subject and compound symmetry covariance structure specified to correct for clustering of teats within cows. As there were very few problematic teat conditions observed, we encountered convergence issues with the full model. As recommended by Kiernan (2018), a forward selection process was applied, keeping only those variables that produced $P<0.05$ results.

\section{Parlor Performance}

Milking Duration Assessment. The effect of the FCV system on the milking duration of cows milked with a rotary parlor system was modeled by fitting a treatment-specific distribution function to the data for all cow-level milkings obtained from the study farm. Several distribution types were examined (normal, lognormal, exponential, Weibull, $\beta$, gamma), of which the gamma distribution provided the best fit to the observations based on the Kolmogorov-Smirnov, Cramer-von Mises, and Anderson-Darling criteria.

The minimum turn time of a rotary parlor is influenced by the maximum milking duration of cows on the platform. To assess whether there are daily differences in maximum milking duration, the daily 80th, 95th, and 99th percentile of milking durations predicted from the gamma distributions were derived for the pooled CON treatments (CON-1 and $\mathrm{CON}-2)$ and for the FCV treatment from single milkings. The mean (and SD) of the daily 80th, 95th, and 99th percentiles were subsequently determined for each vacuum control system.

\section{Parlor Efficiency Simulation}

A stochastic Monte Carlo simulation model in Microsoft Excel (http://www.microsoft.com/) using @Risk add-in software (Palisade Corporation) was developed to estimate the total milking time and annual labor costs in large dairy herds with a rotary milking parlor. Seven different herd sizes, with three matching parlor sizes (Table 1), were modeled in which each analysis consisted of 10,000 iterations. A scenario with CON vacuum control was compared with a scenario with FCV.

With rotary parlors, it is typical to either detach milking units early for slow milking cows or to allow these cows a second rotation. Three scenarios were therefore evaluated. The first scenario assumed that $80 \%$ of the cows finished milking at the end of rotation with the remaining $20 \%$ of cows going on a second rotation ("go-around cows"), typical of practices in block-calving, pasture-based systems. The other 2 scenarios, more typical of North American and European practice, assumed a forced take-off when cows did not finish their milking but were nonetheless at the end of their rotation. In the second scenario, $95 \%$ of the cows were assumed to finish milking at the end of rotation, whereas in the third scenario, $99 \%$ of the cows were assumed to finish milking at the end of rotation.

To represent stochasticity in the simulation model, gamma probability distribution was used to determine the maximum MD for each of the 10,000 individual milking session iterations from the Monte Carlo simulation. The resulting distribution of maximum MD was modeled by a normal distribution using the mean (and SD) for the 80th, 95th, and 99th percentiles. The speed 
of the rotary (second/stall) was subsequently calculated by dividing the maximum milking duration by the size of the rotary minus the number of nonutilized milking units due to cows entering and exiting the parlor, udder preparation and cluster attaching, and postmilking teat disinfection (Table 1).

The throughput of the parlor (cows/hour) in scenario 2 and 3 was calculated by dividing $3,600 \mathrm{~s}$ by the speed of the rotary. In scenario 1, the following formula was applied to estimate the throughput while accounting for the 20\% "go-around cows" (Edwards et al., 2012):

$$
\text { Throughput }=\frac{3,600}{\left(\frac{\text { go-around" } \%+100}{100}\right) \times \text { rotary speed }} .
$$

The size of the herd was divided by the parlor throughput to calculate the total milking time of the herd. The total milking time of the herd was multiplied by the number of employees to calculate the number of person-hours needed for milking the entire herd once. This number was multiplied by 2 and 365 (the total number of milkings per year, assuming cows were milked twice daily) to estimate the number of annual man-hours needed for milking and was multiplied by the hourly wage $(\$ 16.31$; United States Department of Labor, 2020) to estimate the annual labor costs associated with milking.

The return on investment for FCV was estimated as an annual benefit-cost ratio (B:C) as follows:

$\mathrm{B}: \mathrm{C}=\frac{\text { annual labor costs } C O N-\text { annual labor costs } F C V}{\left(\begin{array}{l}\text { annualized capital costs }+ \\ \text { annual maintenance costs }\end{array}\right) \times \text { number of stalls }}$

where the annualized capital costs were the sum of the depreciation and interest costs per stall, and the annual maintenance costs were per milking stall. Interest costs were calculated based on the average value [(purchase

Table 2. Least squares means of outcome variables for milking performance analysis

\begin{tabular}{lcc}
\hline Item $^{2}$ & CON & FCV \\
\hline PMF (kg/min) & $4.25^{\mathrm{a}}$ & $4.75^{\mathrm{b}}$ \\
AMF (kg/min) & $2.24^{\mathrm{a}}$ & $2.35^{\mathrm{b}}$ \\
MD (s) & $311^{\mathrm{a}}$ & $296^{\mathrm{b}}$ \\
\hline
\end{tabular}

\footnotetext{
${ }^{\mathrm{a}, \mathrm{b}}$ Within a row, differing superscripts indicate differences at $P<$ 0.0001 significance level.

${ }^{1} \mathrm{CON}=$ conventional vacuum system $; \mathrm{FCV}=$ flow-controlled vacuum. ${ }^{2} \mathrm{PMF}=$ peak milk flowrate; $\mathrm{AMF}=$ average milk flowrate; $\mathrm{MD}=$ milking duration.
}

value minus salvage value)/2]. Given a higher purchase value of $\mathrm{FCV}$ in comparison with $\mathrm{CON}$ of $\$ 650$ per stall, a salvage value of $\$ 0$, maintenance costs of $\$ 50$ / stall per year, a depreciation time of $10 \mathrm{yr}$, and an interest of $4 \%$ (Martin Wiedemann, DeLaval International, personal communication), the capital costs and maintenance costs were assumed to be respectively $\$ 78$ and $\$ 50 /$ stall per year.

\section{RESULTS AND DISCUSSION}

\section{Milking Speed}

The LS mean of PMF for FCV $(4.75 \mathrm{~kg} / \mathrm{min})$ was $12 \%$ higher $(P<0.0001)$ than for CON $(4.25 \mathrm{~kg} / \mathrm{min}$; Table 2). This result agrees with that of Ambord and Bruckmaier (2010), who also reported an increase in PMF for the 2 types of FCV applied to 10 cows milked with a high-level milkline system. Peak milk flowrate increased by $0.12 \mathrm{~kg} / \mathrm{min}$ for each $1-\mathrm{kg}$ increase in milk yield per milking $(P<0.0001)$. Multiparous cows had $0.16 \mathrm{~kg} / \mathrm{min}$ higher $(P<0.0001)$ PMF $(4.58 \mathrm{~kg} / \mathrm{min})$ than did primiparous cows $(4.42 \mathrm{~kg} / \mathrm{min})$, and a $100-\mathrm{d}$ increase in DIM resulted in a $0.04 \mathrm{~kg} / \mathrm{min}$ reduction in PMF $(P<0.0001)$. The PMF values in our study were somewhat higher than for a field study of 82 Italian herds by Sandrucci et al. (2007), who reported PMF of $3.53 \mathrm{~kg} / \mathrm{min}$ for primiparous cows and $3.92 \mathrm{~kg} / \mathrm{min}$ for multiparous cows and a negative association between PMF and DIM.

The LS mean of AMF for FCV $(2.35 \mathrm{~kg} / \mathrm{min})$ was $4 \%$ higher $(P<0.0001)$ than for CON $(2.24 \mathrm{~kg} / \mathrm{min})$, also in agreement with Ambord and Bruckmaier (2010), who reported a 3\% increase in AMF when FCV was applied (Table 2). Average milk flowrate increased by 0.15 $\mathrm{kg} / \mathrm{min}$ for each 1-kg increase in milk yield per milking $(P<0.0001)$. Multiparous cows had $0.16 \mathrm{~kg} / \mathrm{min}$ lower $(P<0.0001)$ AMF $(2.21 \mathrm{~kg} / \mathrm{min})$ than did primiparous cows $(2.37 \mathrm{~kg} / \mathrm{min})$, and each $100-\mathrm{d}$ increase in DIM resulted in a $0.04 \mathrm{~kg} / \mathrm{min}$ increase in $\operatorname{AMF}(P<0.0001)$. These results are comparable in magnitude to the field study of Sandrucci et al. (2007); however, although we observed a $7 \%$ reduction in AMF in multiparous cows, they reported a $4 \%$ increase $(2.38 \mathrm{~kg} / \mathrm{min}$ for primiparous cows and $2.47 \mathrm{~kg} / \mathrm{min}$ for multiparous cows).

The LS mean of MD for FCV (296 s) was $4 \%$ lower $(P<0.0001)$ than for CON (311 s; Table 2). Each 1 -kg increase in milk yield per milking increased MD by $8.5 \mathrm{~s}(P<0.0001)$, and the reduction in $\mathrm{MD}$ for FCV increased as milk yield per milking increased as illustrated in Figure 1. Primiparous cows had $17 \mathrm{~s}$ lower MD than did multiparous cows $(P<0.0001)$, and each $100-d$ increase in DIM resulted in a $4 \%$ decrease in MD $(P<0.0001)$. Ambord and Bruckmaier (2010) did 
not find a difference in MD in their study of FCV. This may be due to differences in the vacuum dynamics when FCV was applied to a high-level milkline system as compared with our application to a low-level milkline system. In the aforementioned study, short milktube vacuum averaged $46 \mathrm{kPa}$ during the peak and $36 \mathrm{kPa}$ during the low flow periods of milking for one FCV treatment and $34 \mathrm{kPa}$ in the peak and $38 \mathrm{kPa}$ in the low flow periods for the other. In our study, short milktube vacuum averaged $42 \mathrm{kPa}$ during the peak and $40 \mathrm{kPa}$ during the low flow periods.

Our study was not designed to detect differences in milk yield or mastitis risk. We did, however, examine milk yield and bulk tank SCC data and saw no evidence suggesting a change in either that could be attributed to the vacuum control treatment, nor did the farm manager note any changes or concerns. Stage of lactation and lactation number were associated $(P<$ $0.0001)$ with milk yield as would be expected. When daily average milk yield per cow was corrected for DIM, there was no difference $(P=0.97)$ between the CON-1 and FCV periods, and the CON-2 period had slightly lower $(P<0.0001)$ daily average milk yield per cow than either $\mathrm{CON}-1$ or FCV treatment periods. Bulk tank SCC averaged 143,000 cells/mL during the study period and were not associated with treatment $(P=$ $0.77)$.

\section{Teat Condition}

Teat-End Hyperkeratosis. The McNemar's test comparing scores at the end of the FCV to the prior CON-1 period showed that $92.9 \%$ of teat ends $(2,324$ teats on 581 cows) were smooth for both periods, $1.3 \%$ of teats had roughened ends for both periods, $1.6 \%$ of teats changed from smooth to rough ends, and $4.2 \%$ of teats changed from rough to smooth ends (Table $3 ; P$ $<0.001)$. There was no difference in the distribution of TEHK scores at the end of the CON-2 period as compared with the end of the FCV period $(P=0.098 ; 2,656$ teats on 664 cows). The GLIMMIX analysis resulted in 3 significant effects; a 1-cm increase in teat length increased the odds of roughened teat ends by $130 \%$ $(P<0.0001)$, a 10 -s decrease in MD reduced the odds of roughened teat ends by $6 \%(P<0.0001)$, and $\mathrm{L} 2+$ cows had $150 \%$ increased odds of roughened teat ends $(P<0.0001)$ compared with L1 cows. The 9 -wk study period was chosen to be long enough for changes in TEHK to manifest and short enough to reduce the risk of confounding results from seasonal changes in TEHK. Although it may take somewhat longer than 3 wk for TEHK to stabilize, the majority of this change of state was expected to manifest during the 3 -wk period. The

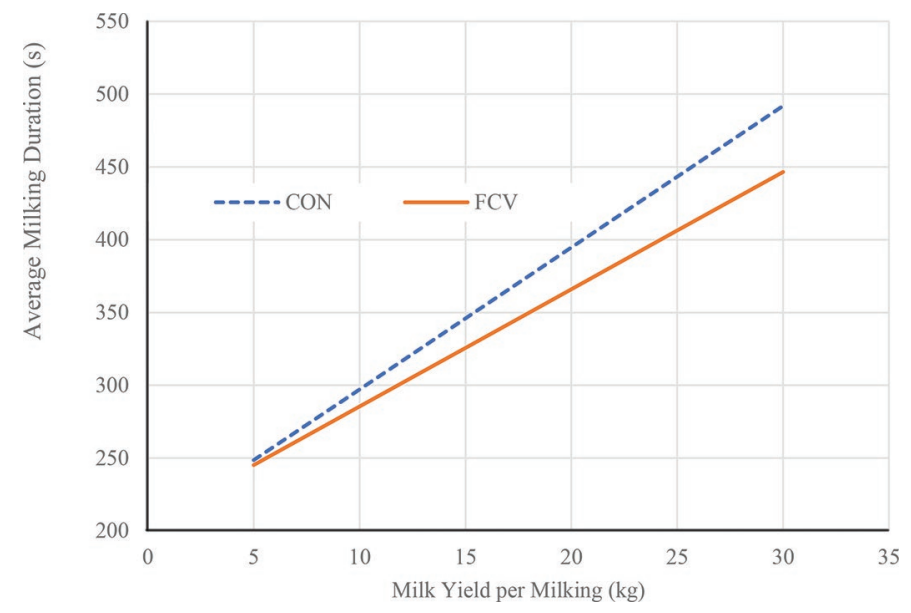

Figure 1. Relationship of milk yield per milking and milking duration for constant vacuum control $(\mathrm{CON})$ and flow-controlled vacuum (FCV) periods illustrating that milking duration is affected by both milk yield per milking and the vacuum control strategy with increasing effect of vacuum control as milk yield per milking increases.

results of the statistical model for TEHK indicated that a higher percentage of teat ends changed from rough to smooth $(4.2 \%)$ than from smooth to rough $(1.6 \%)$ during the FCV period.

Teat Color. The McNemar's test comparing the FCV to that of the prior CON-1 period showed that $97.1 \%$ of teat ends had no blue color for both periods, $0.2 \%$ of teats were blue colored for both periods, $0.9 \%$ of teats changed to blue colored, and $1.9 \%$ of teats changed from blue to not-blue colored (Table $3 ; P=$ 0.004). The comparison of the CON-2 to the prior FCV period showed that $97.5 \%$ of teat ends had no blue color for both scoring sessions, $1.6 \%$ of teats went from blue to not-blue, and $0.9 \%$ of teats went from normal to blue $(P=0.027)$. The statistical analysis showed that a 10 -s decrease in MD reduced the odds of blue teats by $12 \%(P<0.0001)$.

Teat Ringing. The McNemar's test comparing the FCV to the prior CON-1 period did not identify a change in the status of palpable rings (Table $3 ; P$ $=0.059)$, although there was a trend with more teats losing than gaining palpable rings. The comparison of the CON-2 period to the FCV period resulted in $1.2 \%$ losing and $0.6 \%$ of teats gaining palpable rings $(P=$ $0.032)$. The statistical analysis showed that a $10-\mathrm{s}$ decrease in MD reduced the odds of severe teat ringing by $8 \%(P=0.004)$.

Petechiation. Less than $0.4 \%$ of teats were observed to have petechial hemorrhaging during the entire study period. The distribution of teats with petechiae teats did not change when the FCV was applied $(P=0.109)$ nor when $\mathrm{CON}-2$ was reapplied (Table $3 ; P=0.366$ ). 
Reinemann et al.: FLOW-CONTROLLED VACUUM

Table 3. Results of McNemar test of teat condition observations ${ }^{1}$

\begin{tabular}{|c|c|c|c|c|c|}
\hline Item $^{2}$ & $\mathrm{~N}-\mathrm{N}$ & $\mathrm{N}-\mathrm{P}$ & $\mathrm{P}-\mathrm{N}$ & P-P & $\operatorname{Pr}>\chi^{2}$ \\
\hline \multicolumn{6}{|c|}{$\%$ rough or very rough teat ends } \\
\hline CON-1 to FCV & 92.9 & 1.6 & 4.2 & 1.3 & $<0.001$ \\
\hline FCV to $\mathrm{CON}-2$ & 94.2 & 2.6 & 2.2 & 1.1 & 0.098 \\
\hline \multicolumn{6}{|l|}{$\%$ blue teats } \\
\hline $\mathrm{CON}-1$ to $\mathrm{FCV}$ & 97.1 & 0.9 & 1.9 & 0.2 & 0.004 \\
\hline FCV to $\mathrm{CON}-2$ & 97.5 & 0.9 & 1.6 & 0.0 & 0.027 \\
\hline \multicolumn{6}{|c|}{$\%$ teats with palpable rings } \\
\hline $\mathrm{CON}-1$ to $\mathrm{FCV}$ & 96.5 & 1.4 & 2.1 & 0.0 & 0.059 \\
\hline FCV to $\mathrm{CON}-2$ & 98.6 & 0.6 & 1.2 & 0.0 & 0.032 \\
\hline \multicolumn{6}{|c|}{$\%$ of teats with petechia } \\
\hline $\mathrm{CON}-1$ to $\mathrm{FCV}$ & 99.4 & 0.4 & 0.2 & 0.0 & 0.109 \\
\hline FCV to $\mathrm{CON}-2$ & 99.6 & 0.2 & 0.3 & 0.0 & 0.366 \\
\hline
\end{tabular}

${ }^{1} \mathrm{~N}-\mathrm{N}$ indicates the percentage of teats that were negative for both periods. N-P indicates the percentage of teats that changed from negative to positive. P-N indicates the percentage of teats the changed from positive to negative. P-P indicates the percentage of teats that were positive for both periods.

${ }^{2}$ The CON-1 (conventional vacuum system) observations were done before the FCV (flow-controlled vacuum) period. The FCV observations were done after 3 wk of using FCV. The CON-2 observations were done after 3 wk of return to the constant vacuum control system. The comparison of CON-1 to FCV represents 2,324 paired individual teat observations. The comparison of FCV to CON-2 represents 2,656 paired individual teat observations.

None of the variables tested with the statistical model were associated with teat skin petechia.

Teat condition on this farm was very good during the whole experimental period with all of the categories scored well below thresholds recommended by Mein et al. (2001). This is an indication that the liner used on this farm fit the majority of teats well and did not apply excessive compression to teat ends. Liner fit has been previously identified as the most influential factor on teat condition by Mein et al., (2013). A similarly low rate of rough teat ends was observed by Haeussermann et al. (2016) with the same liner used in our study. The CON-1, FCV, and CON-2 treatment periods were confounded with time, so it is not possible to conclude a causal relationship. The repeat of the CON method after application of the FCV method was to provide some insight into changes over time that might be unrelated to the vacuum control method. The evidence strongly suggests that the vacuum control method had a very small influence on teat condition and that there was little change in teat condition over the entire study period.

The FCV method may have reduced the risk of developing roughened teat ends very slightly. This is a biologically plausible effect. The increase in teat-end vacuum produced by FCV would be expected to produce a small increase $(<10 \%)$ in liner compression and TEHK risk during the peak flow period (Mein et al., 2013). On the other hand, the FCV treatment reduced MD, which has been associated with reduced TEHK (Zucali et al., 2008). In our study it appeared as if the effect of reduced MD reduced TEHK risk more than possible effects of increased milking vacuum level dur- ing the peak flow period of milking. Longer teats had higher odds of developing rough teat ends, probably because they penetrate into regions of higher liner compression (Mein et al., 2013).

The teat-end vacuum during the low flow period was the same for both CON and FCV in our study. We would therefore expect no effect on teat color or ringing associated with vacuum level, a hypothesis supported by Besier and Bruckmaier (2016), who concluded that teat condition was mainly dependent on the vacuum applied to teat tissue during the low flow period at the end of milking. Quarters finish milking at different times, resulting in some quarters with no or very low milk flow while the cluster is still attached. In our study the flow threshold for teatcup removal was $0.4 \mathrm{~kg} / \mathrm{min}$ at the udder level. Using the prediction of Silva Boloña et al. (2020), the difference between the first and last quarter to finish milking for our teatcup removal settings is estimated to be $1.5 \mathrm{~min}$, meaning that on average, the first quarters to finish would be overmilked by $1.5 \mathrm{~min}$ at the time the milking unit was removed. The volume of milk in the teat sinus is substantially reduced in the low flow/high-vacuum period at the end of milking, resulting in teats becoming narrower and longer and increased mouthpiece chamber vacuum. This results in the teat barrel being exposed to higher vacuum levels, which can compromise circulation in both the teat-end and teat-barrel tissues (Penry et al., 2017). The association between reduced MD and reduced occurrence of blue colored teats and palpable teat rings is likely a result of the reduction of overmilking for early milked out quarters. It appears that any potential negative influence of increased teat-end vacuum during 
the peak flow period were largely avoided by a reduction in $\mathrm{MD}$ and resulting reduction in overmilking of some quarters. This hypothesis is supported by Odorčić et al. (2020), who found that teat wall thickness was primarily affected by overmilking. Our experiment was performed with a cluster removal flow threshold of 0.4 $\mathrm{kg} / \mathrm{min}$. It is likely that the small increase in short-term teat tissue stress would be reduced by using a strategy that removed clusters earlier, further reducing milking duration and the overmilking of some quarters (Rasmussen, 1993, 2000; Hillerton et al., 2002). Our results on teat tissue condition for a large number of cows on a low-level milkline system are also in agreement with a previous study of two different FCV strategies applied on a high-level milkline system with a sample size of 10 cows (Ambord and Bruckmaier, 2010) that reported no increase in teat wall thickness for either system.

There are several other ways to reduce cow milking duration. In our study, cow MD was reduced by $4 \%$ when applying FCV. The model results of Silva Boloña et al. (2020) showed that MD could be reduced by about $20 \%$ by increasing flow thresholds from 0.2 to $1.0 \mathrm{~kg} / \mathrm{min}$ or about $5 \%$ for each increase of $0.2 \mathrm{~kg} / \mathrm{min}$. We used a flow threshold of $0.4 \mathrm{~kg} / \mathrm{min}$ in our study, which may explain why we found a significant reduction in MD, whereas Ambord and Bruckmaier (2010), who used a flow threshold of $0.2 \mathrm{~kg} / \mathrm{min}$, did not. Penry et al. (2017) reported that AMF could be increased by about $20 \%$ for a high-compression liner and about $10 \%$ for a low-compression liner by increasing pulsator ratio from 50:50 to 70:30, with interactive effects of milking vacuum. The model results from Penry et al. (2017) suggest that the effects of vacuum and pulsation can be additive, provided that the correct liner is used. Optimizing the specific vacuum levels used in FCV with pulsation and cluster removal settings, and application at the quarter versus cluster level is an area of ongoing research.

\section{Milking Parlor Performance}

The gamma distributions of $\mathrm{MD}$ for $\mathrm{CON}$ and $\mathrm{FCV}$ are illustrated in Figure 2. These distributions, derived from single cow milkings, served as the basis to derive the mean daily distribution of MD at herd level. The 80 th $($ mean $=354 \mathrm{~s} ; \mathrm{SD}=10), 95$ th $($ mean $=433 \mathrm{~s} ; \mathrm{SD}$ $=14)$, and 99th $($ mean $=504 \mathrm{~s} ; \mathrm{SD}=24)$ percentiles of the mean daily MD for FCV were 4 to $6 \%$ lower than for CON (80th: mean $=370 \mathrm{~s}, \mathrm{SD}=9$; 95th: mean $=$ $458 \mathrm{~s}, \mathrm{SD}=14 ;$ and 99th: mean $=538 \mathrm{~s}, \mathrm{SD}=19$ ).

The reduction in mean daily $\mathrm{MD}$, due to the FCV system, resulted in a reduced turn time according to the simulation model (Figure 3). The largest absolute increase in rotary parlor speed was observed for the scenario with a 60 -cow parlor and $95 \%$ of cows finishing their milking at the end of rotation. In this situation, the speed could be increased by $0.60 \mathrm{~s}$ per stall, whereas the increase was the lowest at $0.20 \mathrm{~s}$ per stall for a 100-cow parlor with $80 \%$ of cows finishing their milking at the end of rotation. The increase in rotary parlor speed resulted in an increased parlor throughput for all 3 scenarios and all 3 parlor sizes. For example, in the $80 \%$ (and $20 \%$ go-around) scenario, the average (5\% and $95 \%$ percentiles) parlor throughput increased from $399(383-416)$ to $419(401-439)$ cows/h for a 60 cow rotary parlor, whereas this was from 381 (362-402) to 407 (385-430) cows/h for the $95 \%$ scenario and from $313(296-331)$ to $326(302-351)$ cows/h for the $99 \%$ scenario. The increased parlor throughput subsequently resulted in a reduction in time required to milk the herd (Table 4). For a 1,000-cow herd the average total milking time was $0.2 \mathrm{~h}$ shorter with $95 \%$ of cows finishing their milking at the end of rotation, whereas this increased to almost $0.7 \mathrm{~h}$ for a herd with 7,000 cows. With $95 \%$ of cows finishing their milking at the end of rotation, this resulted in an annual labor cost reduction of $\$ 7,989$ for a 1,000 -cow herd, increasing to $\$ 56,169$ for a 7,000-cow herd (Table 5). Based on cautionary and preliminary price estimations, the $\mathrm{B}$ : $\mathrm{C}$ was positive for all scenarios except the 1,000-cow herd with a 60-stall rotary parlor (Table 5). The B:C increased with increasing herd and parlor size with a maximum value of 4.4 for the 7,000 -cow herd with a 100 -cow rotary parlor using the 95th percentile setting.

Within this bioeconomic simulation model, it was assumed that either 95 or $99 \%$ of cows had their milking clusters taken off to leave the rotary platform or that $20 \%$ of cows would go on a second rotation. The parlor throughput was slightly higher in the $80 \%$ (with $20 \%$ "go-around" cows) scenario compared with the 95\% scenario for all 3 simulated parlor sizes. It was beyond the scope of the current investigation to compare parlor efficiencies of the 3 scenarios. They should therefore be interpreted to reflect different parlor efficiency procedures that may exist in different regions of the world. On the other hand, and regardless of the scenario, the FCV system always outperformed the CON system, resulting in a higher parlor throughput and lower associated annual labor costs. The relative improvement in parlor efficiency due to the FCV system was the highest in the $95 \%$ scenario. This was a result of the relative decrease in MD due to the FCV system, which was the largest for the 95th percentile compared with the 80th and 99th percentiles (Figure 2 ). Farmers who apply the $95 \%$ scenario may thus benefit most from the FCV system compared with those milking with the $80 \%$ (with $20 \%$ "go-around" cows) or $99 \%$ scenario. 


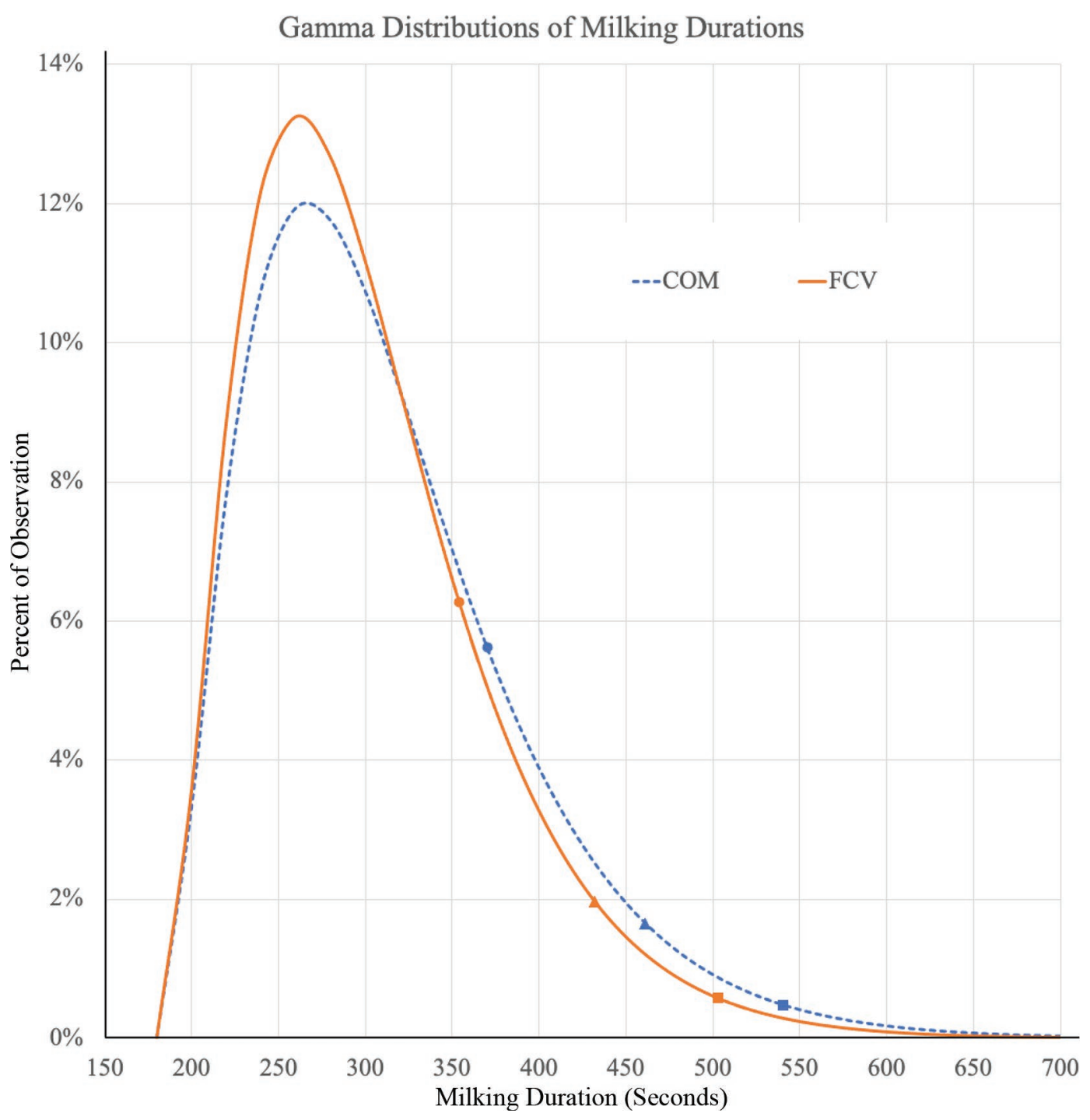

Figure 2. Distribution of milking durations for the study herd using both the constant vacuum control (CON) and the flow-controlled vacuum $(\mathrm{FCV})$. Circle $=80$ th percentile, triangle $=95$ th percentile, square $=99$ th percentile.

In addition to the milking duration of cows, the speed of the rotary platform is also determined by the capacity of the milkers for udder preparation and attaching. Here it was assumed that milkers are still able to perform their activities despite the shorter time available for preparation and attaching of clusters. For a 60 -cow rotary parlor with 2 milkers, platform speed was reduced to $7.2 \mathrm{~s}$ per cow on average when using the FCV system with $80 \%$ of cows finishing their milking at the end of rotation. This is close to the mean platform speed of $6.8 \mathrm{~s} /$ cow observed by Edwards et al. (2012), implying that increasing the platform speed to such values by applying the FCV system is feasible. On the other hand, the platform speed was on average $4.1 \mathrm{~s} /$ cow when using the FCV system in a 100-cow rotary parlor, but it is uncertain whether the milkers working in such a situation are able to complete their work with a sufficient level of quality.

The 4 to $6 \%$ reduction in MD due to the FCV resulted in potentially large annual labor costs savings and a high B:C. When calculating the B:C, the annualize capital costs per stall were based on a 60-cow rotary parlor and assumed to be constant for all 3 parlor sizes. In reality, the annualized cost per stall would likely be lower for larger rotary parlors. We assumed a labor rate of $\$ 16 / \mathrm{h}$, which is the average wage of farm workers in the United States and likely lower than the total cost of labor in most parts of the world. We also assumed 2 milkings per day, whereas the larger farms modeled would likely be milking 3 times per day. The calculated 
Table 4. Estimated mean (and 5th and 95th percentile in parentheses) of the total hours per milking for herds with a different size when applying the conventional (CON) vacuum system or the flow-controlled vacuum system $(\mathrm{FCV})^{1}$

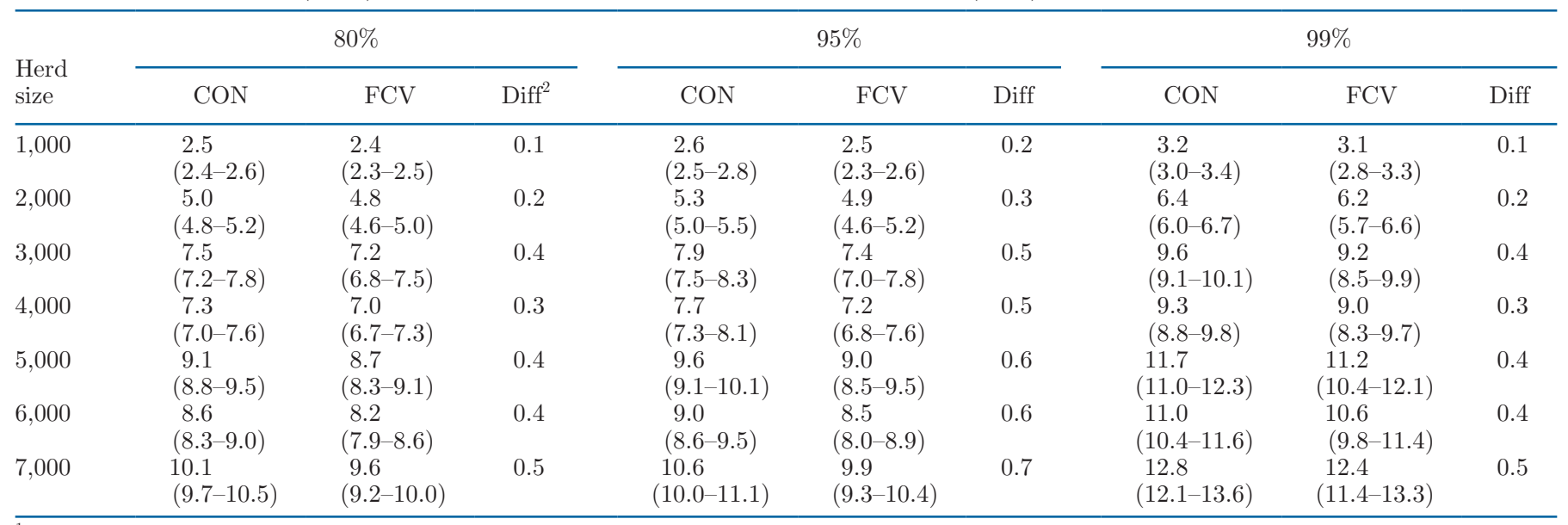

${ }^{1}$ Systems were applied according to whether 80,95 , or $99 \%$ of cows were finished milking at the end of rotation. In the $80 \%$ scenario, $20 \%$ of cows went on a second rotation, whereas a forced takeoff was assumed for cows in the $95 \%$ and $99 \%$ scenarios.

${ }^{2}$ Diff $=$ difference.

$\mathrm{B}: \mathrm{C}$ values are therefore considered conservative for most situations.

The bioeconomic model estimated the reduction in annual labor costs by simulating the reduction in total annual person-hours given the same herd and parlor size. Another modeling strategy would be to calculate the opportunity costs by utilizing this available parlor capacity to milk more cows. However, this strategy was

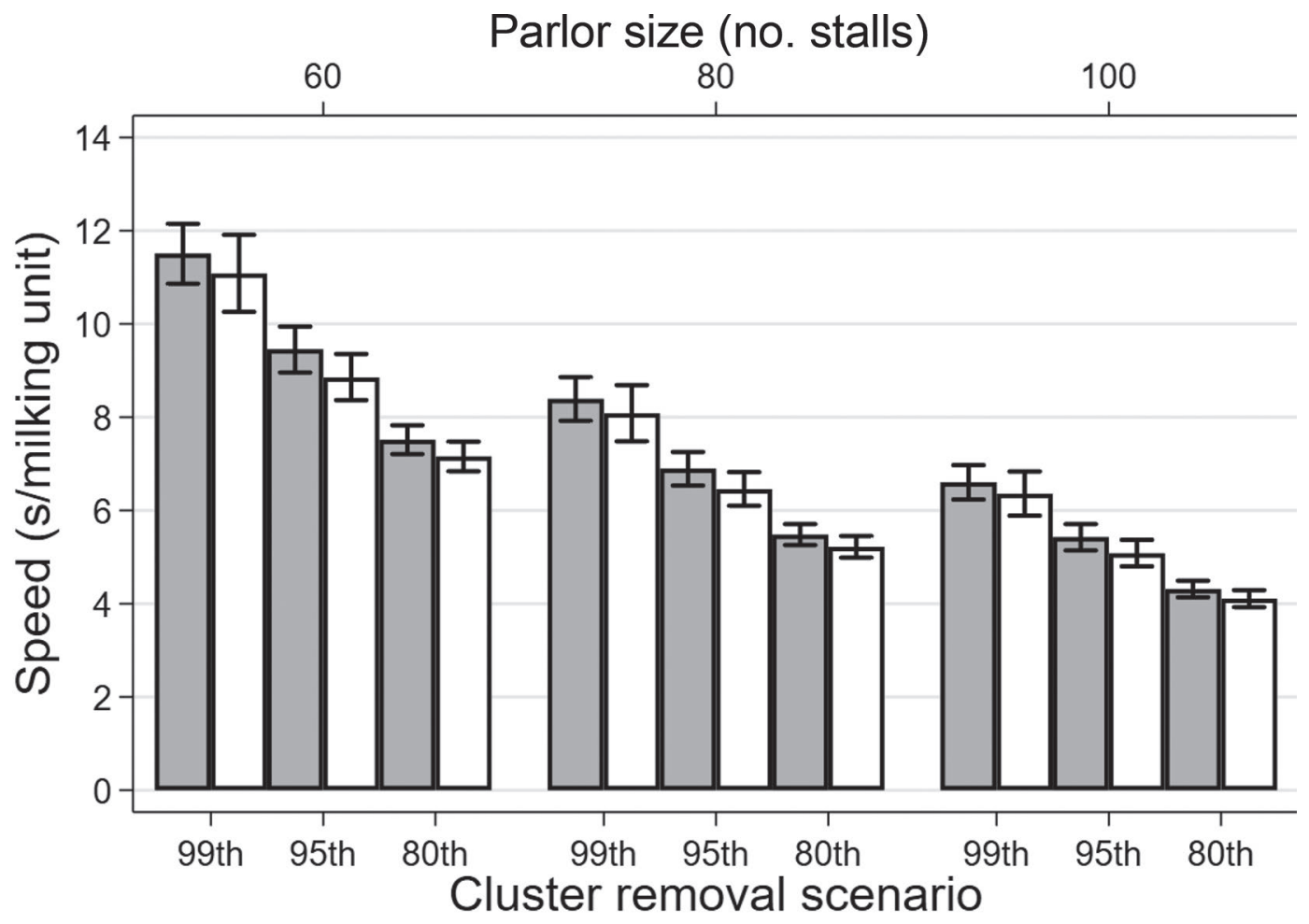

Figure 3. Average (and 5th and 95th percentile) speed of 3 rotary milking parlor sizes using the conventional vacuum system (gray bars) or the flow-controlled vacuum system (white bars) when 80,95 , and $99 \%$ of cows have finished their milking at the end of rotation. In the 80 th scenario, $20 \%$ of cows go on a second rotation, whereas a forced takeoff was assumed for cows in the 95th and 99th percentile cluster removal scenarios. 
Table 5. Mean (5th and 95th percentile in parentheses) annual labor costs $(\times \$ 1,000)$ and the return on investment as an annualized BenefitCost ratio (B:C) when applying the conventional (CON) vacuum system or the flow-controlled vacuum system (FCV) according to whether 80 , 95 , or $99 \%$ of cows are finished milking at the end of rotation ${ }^{1}$

\begin{tabular}{|c|c|c|c|c|c|c|c|c|c|c|c|c|}
\hline $\begin{array}{l}\text { Herd } \\
\text { size }\end{array}$ & \multicolumn{4}{|c|}{$80 \%$} & \multicolumn{4}{|c|}{$95 \%$} & \multicolumn{4}{|c|}{$99 \%$} \\
\hline 1,000 & $\begin{array}{l}119 \\
(114-124)\end{array}$ & $\begin{array}{l}114 \\
(109-119)\end{array}$ & 6 & 0.7 & $\begin{array}{l}125 \\
(119-132)\end{array}$ & $\begin{array}{l}117 \\
(111-124)\end{array}$ & 8 & 1.0 & $\begin{array}{l}152 \\
(144-161)\end{array}$ & $\begin{array}{l}147 \\
(136-158)\end{array}$ & 6 & 0.7 \\
\hline 2,000 & $\begin{array}{l}239 \\
(229-248)\end{array}$ & $\begin{array}{l}227 \\
(217-237)\end{array}$ & 11 & 1.5 & $\begin{array}{l}250 \\
(237-263)\end{array}$ & $\begin{array}{l}234 \\
(221-248)\end{array}$ & 16 & 2.1 & $\begin{array}{l}304 \\
(287-321)\end{array}$ & $\begin{array}{l}293 \\
(271-315)\end{array}$ & 11 & 1.5 \\
\hline 3,000 & $\begin{array}{l}358 \\
(343-373)\end{array}$ & $\begin{array}{l}341 \\
(326-356)\end{array}$ & 17 & 2.2 & $\begin{array}{l}375 \\
(356-395)\end{array}$ & $\begin{array}{l}351 \\
(332-371)\end{array}$ & 24 & 3.1 & $\begin{array}{l}457 \\
(431-482)\end{array}$ & $\begin{array}{l}440 \\
(407-473)\end{array}$ & 17 & 2.2 \\
\hline 5,000 & $\begin{array}{l}653 \\
(626-680)\end{array}$ & $\begin{array}{l}622 \\
(594-649)\end{array}$ & 31 & 3.0 & $\begin{array}{l}684 \\
(648-720)\end{array}$ & $\begin{array}{l}641 \\
(605-677)\end{array}$ & 44 & 4.3 & $\begin{array}{l}833 \\
(786-879)\end{array}$ & $\begin{array}{l}802 \\
(742-862)\end{array}$ & 31 & 3.0 \\
\hline 6,000 & $\begin{array}{l}719 \\
(690-749)\end{array}$ & $\begin{array}{l}685 \\
(654-715)\end{array}$ & 34 & 2.7 & $\begin{array}{l}754 \\
(714-793)\end{array}$ & $\begin{array}{l}706 \\
(667-746)\end{array}$ & 48 & 3.8 & $\begin{array}{l}918 \\
(866-968)\end{array}$ & $\begin{array}{l}883 \\
(818-950)\end{array}$ & 34 & 2.7 \\
\hline 7,000 & $\begin{array}{l}839 \\
(805-874)\end{array}$ & $\begin{array}{l}799 \\
(763-834)\end{array}$ & 40 & 3.1 & $\begin{array}{l}880 \\
(833-925)\end{array}$ & $\begin{array}{l}823 \\
(778-870)\end{array}$ & 56 & 4.4 & $\begin{array}{l}1,070 \\
(1,010-1,130)\end{array}$ & $\begin{array}{l}1,031 \\
(954-1,108)\end{array}$ & 40 & 3.1 \\
\hline
\end{tabular}

${ }^{1}$ In the $80 \%$ scenario, $20 \%$ of cows went on a second rotation, whereas a forced take-off was assumed for cows in the $95 \%$ and $99 \%$ scenarios.

${ }^{2}$ Diff $=$ difference

not chosen for reasons of simplicity because it would involve modeling the expansion of the herd, taking into account barn capacity and the gross margin of the cows. Alternatively, the increased capacity may also be a reason for farmers to opt for a smaller sized parlor when buying a new rotary parlor. The simulation model developed in this study can be used as a starting point to develop a tool to assist farmers who want to invest in an FCV system in addition to their current rotary parlor or assist those considering buying a new rotary parlor.

\section{CONCLUSIONS}

The FCV strategy reverses the relationship between increased milk flowrate and decreased teat-end vacuum as occurs with conventional vacuum control. Applying higher teat-end vacuum during the peak milk flow period of milking was shown to increase PMF by $12 \%$, increase $\mathrm{AMF}$ by $4 \%$, and decrease MD by $4 \%$. The decrease in MD was proportional to milk yield per milking. Changes in postmilking visual assessment of short-, medium- and long-term teat tissue conditions showed very little effect of the FCV control system. The evidence suggests that there was a slight trend toward reduced teat-end roughness with no meaningful difference in the occurrence of teats with blue color, palpable rings, or petechiae. The combination of reduced vacuum during the low flow period of milking and the decrease in MD are likely factors that are protective of teat tissues. Bioeconomic simulation modeling of the use of FCV in rotary milking parlors showed that the reduction in milking duration of individual cows resulted in a shorter total milking time in rotary milking parlors where cows have their milking clusters taken off at the end of their first rotation or when $20 \%$ of the cows go on a second rotation. This demonstrated the potential for the FCV system to achieve increased labor efficiency, reduced labor costs for milking, and a B:C of over 4 for large rotary milking parlors.

\section{ACKNOWLEDGMENTS}

The authors express their gratitude to the study farm for their participation. This study was funded by DeLaval International. M. Wiedemann and C. O. Paulrud are employed by DeLaval and declare a potential conflict of interest. The other authors have not stated any conflicts of interest.

\section{REFERENCES}

Ambord, S., and R. M. Bruckmaier. 2010. Milk flow-dependent vacuum loss in high-line milking systems: Effects on milking characteristics and teat tissue condition. J. Dairy Sci. 93:3588-3594. https: //doi.org/10.3168/jds.2010-3059.

Bade, R. D., D. J. Reinemann, M. Zucali, P. L. Ruegg, and P. D. Thompson. 2009. Interactions of vacuum, b-phase duration, and liner compression on milk flow rates in dairy cows. J. Dairy Sci. 92:913-921. https://doi.org/10.3168/jds.2008-1180.

Besier, J., and R. M. Bruckmaier. 2016. Vacuum levels and milk-flowdependent vacuum drops affect machine milking performance and teat condition in dairy cows. J. Dairy Sci. 99:3096-3102. https:// doi.org/10.3168/jds.2015-10340.

Besier, J., O. Lind, and R. M. Bruckmaier. 2016. Dynamics of teat-end vacuum during machine milking: types, causes and impacts on teat condition and udder health-A literature review. J. Appl. Anim. Res. 44:263-272. https://doi.org/10.1080/09712119.2015.1031780.

Edwards, J. P., N. Lopez-Villalobos, and J. G. Jago. 2012. Increasing platform speed and the percentage of cows completing a second 
rotation improves throughput in rotary dairies. Anim. Prod. Sci. 52:969-973. https://doi.org/10.1071/AN12071.

Gleeson, D. E., E. J. O'Callaghan, and M. V. Rath. 2003. Effect of vacuum level on bovine teat-tissue and milking characteristics. Ir. J. Agric. Food Res. 42:205-211.

Haeussermann, A., J. Britten, A. Britten, C. Pahl, N. Älveby, and E. Hartung. 2016. Effect of a multi-sided concave liner barrel design on thickness and roughness of teat-end hyperkeratosis. J. Dairy Res. 83:188-195. https://doi.org/10.1017/S0022029916000200.

Hillerton, J. E., J. W. Pankey, and P. Pankey. 2002. Effect of overmilking on teat condition. J. Dairy Res. 69:81-84. https://doi.org/ $10.1017 /$ S0022029901005386.

ISO. 2007. ISO 5707: Milking machine installations - Construction and performance. 3rd ed. Int. Organisation for Standardization (ISO).

Kiernan, K. 2018. Insights into using the GLIMMIX procedure to model categorical outcomes with random effects. Paper SAS21792018, SAS Institute Inc.

Mein, G. A., F. Neijenhuis, W. F. Morgan, D. J. Reinemann, J. E. Hillerton, J. R. Baines, I. Ohnstad, M. D. Rasmussen, L. Timms, J. S. Britt, R. Farnsworth, N. Cook, and T. Hemling. 2001. Evaluation of bovine teat condition in commercial dairy herds: 1 . NonInfectious Factors. Pages 347-351 in Proc. 2nd Int. Symp. on Mastitis and Milk Quality. Natl. Mastitis Council Inc., Vancouver, BC, Canada.

Mein, G. A., D. J. Reinemann, and P. D. Thompson. 2013. Understanding the milking machine: The contribution of cyclic liner compression to effective pulsation. Pages 71-84 in Proc. 2013 Annu. Mtg. Natl. Mastitis Council. NMC, Verona, WI.

Odorčić, M., U. Blau, J. Löfstrand, and R. M. Bruckmaier. 2020. Short communication: Teat wall diameter and teat tissue thickness in dairy cows are affected by intramammary pressure and by the mechanical forces of machine milking. J. Dairy Sci. 103:884-889. https://doi.org/10.3168/jds.2019-16565.

Odorčić, M., M. D. Rasmussen, C. O. Paulrud, and R. M. Bruckmaier. 2019. Review: Milking machine settings, teat condition and milking efficiency in dairy cows. Animal 13:s94-s99. https://doi.org/10 .1017/S1751731119000417.

Penry, J. F., J. Upton, G. A. Mein, M. D. Rasmussen, I. Ohnstad, P. D. Thompson, and D. J. Reinemann. 2017. Estimating teat canal cross-sectional area to determine the effects of teat-end and mouthpiece chamber vacuum on teat congestion. J. Dairy Sci. 100:821-827. https://doi.org/10.3168/jds.2016-11533.

Rasmussen, M. D. 1993. Influence of switch level of automatic cluster removers on milking performance and udder health. J. Dairy Res. 60:287-297. https://doi.org/10.1017/S0022029900027631.

Rasmussen, M. D. 2000. Overmilking and teat condition. Pages 169 175 in Proc. 2004 Annu. Mtg. Natl. Mastitis Council.

Reinemann, D. J., A. M. A. Gomez, P. E. Thompson, and I. Ohnstad. 2013. Exploring the role of liner dimension, shape, and venting on milking performance. Pages 64-70 in Proc. 2013 Annu. Mtg. Natl. Mastitis Council.

Reinemann, D. J., M. D. Rasmussen, S. LeMire, F. Neijenhuis, G. A. Mein, J. E. Hillerton, W. F. Morgan, L. Timms, N. Cook, R. Farnsworth, J. R. Baines, and T. Hemling. 2001. Evaluation of bovine teat condition in commercial dairy herds: 3 . Getting the numbers right. Pages 357-361 Proc. 2nd Int. Symp. on Mastitis and Milk Quality, NMC/AABP, Vancouver, Canada.

Sandrucci, A., A. Tamburini, L. Bava, and M. Zucali. 2007. Factors affecting milk flow traits in dairy cows: Results of a field study. J. Dairy Sci. 90:1159-1167. https://doi.org/10.3168/jds.S0022 -0302(07)71602-8.

Silva Boloña, P., J. Upton, and D. J. Reinemann. 2020. Effects of simulated quarter and udder removal settings on strip milk and milking duration in dairy cows. J. Dairy Sci. 103:4446-4454. https: //doi.org/10.3168/jds.2019-17266.

Smith, V. R., and W. E. Petersen. 1946. The effect of increasing the negative pressure and widening of the vacuum-release ratio on the rate of removal of milk from the udder. J. Dairy Sci. 29:45-53. https://doi.org/10.3168/jds.S0022-0302(46)92442-3.

Spencer, S. B., J. W. Shin, G. W. Rogers, and J. B. Cooper. 2007. Short communication: Effect of vacuum and ratio on the performance of a monoblock silicone milking liner. J. Dairy Sci. 90:17251728. https://doi.org/10.3168/jds.2006-493.

Thomas, C. V., M. A. Delorenzo, and D. R. Bray. 1993. Prediction of individual cow milking time for milking parlor simulation models. J. Dairy Sci. 76:2184-2194. https://doi.org/10.3168/jds.S0022 -0302(93)77555-4.

United States Department of Labor. 2020. Bureau of Labor Statistics: Occupational Employment and Wages, May 2019; 45-2099 Agricultural Workers, All Other. Accessed May 8, 2020. https://www .bls.gov/oes/current/oes452099.htm\#nat.

Zucali, M., D. J. Reinemann, A. Tamburini, and R. D. Bade. 2008 Effects of liner compression on teat-end hyperkeratosis. Paper No. 083798, presented at the 2008 ASABE Annu. Int. Mtg., Providence, Rhode Island. Am. Soc. Agric. Biol. Eng.

\section{ORCIDS}

D. J. Reinemann ( https://orcid.org/0000-0002-1319-0718

B. H. P. van den Borne (1) https://orcid.org/0000-0001-6248-4707

H. Hogeveen ( https://orcid.org/0000-0002-9443-1412

M. Wiedemann ๑ https://orcid.org/0000-0003-4795-8702

C. O. Paulrud ๑ https://orcid.org/0000-0002-2772-8064 